kuzbass.ru/kultura-i-iskusstvo/sibirskiy-klasteriskusstv/?PAGEN_2=2 (28.03.2021).

10. Кемеровский государственный инстиmут культуры. URL: https://kemguki.ru/news/v- kemgik-nachala-svoyu-rabotu-priemnaya-komissiya-filiala-moskovskoy-gosudarstvennoyakademii-khoreo/ (27.03.2021).

УДК 908(571.17)+069

DOI: $10.32340 / 2514-772 X-2021-1-34-40$

Е. А. Ермакова

Средняя общеобразовательная школа № 11 (Кемерово, Россия) ermak200712@mail.ru

Н. Я. Сафронова

Народный краеведческий музей-комплекс имени заслуженного учителя РСФСР Петренко П. М. Средняя общеобразовательная школа №11 (Кемерово, Россия) natali.safronova.57@bk.ru

\title{
ИСТОРИЯ ВОЕННОГО ЗАВОДА № 319 «КОММУНАР» (ПО МАТЕРИАЛАМ ПОИСКОВО-ИССЛЕДОВАТЕЛЬСКОЙ РАБОТЫ КРАЕВЕДЧЕСКОГО МУЗЕЯ-КОМПЛЕКСА СРЕДНЕЙ ОБЩЕОБРАЗОВАТЕЛЬНОЙ ШКОЛЫ № 11 Г. КЕМЕРОВО)
}

Аннотация. С 2020 года в Средней общеобразовательной школе № 11 (г. Кемерово) реализуется проект «Память поколений». Сотрудниками учреждения была проведена поисково-исследовательская работа по восстановлению памяти о заводе «Коммунар»: изучены архивные документы, проведены встречи с ветеранами завода, сбор предметов, касающихся истории завода, собраны воспоминания заводчан и фотоматериалы.

Ключевые слова: история завода, военное время, икольный музей, историко-публицистическое издание.

В свое время И. Эренбург писал: «Для того чтобы патриотизм был крепким и непоколебимым, нужно, чтобы он исходил из любви к своей маленькой родине - родному городу, родной природе, селу, краю». Восстановление и возрождение нашего исторического и духовного наследия, воспитание нравственности, духовности и гражданственности невозможно без уважения к своей истории, культуре, родному краю. Эта проблема крайне актуальна в наши дни и требует к себе особого внимания. Современные дети зачастую знают мало из истории своей малой родины, о Великой Отечественной войне и о людях, которые создавали наше будущее. В связи с этим неуклонно возрастает роль исторического краеведения. Связующей нитью, объединяющей людей разных возрастов, профессий и положения, стала поисковая и исследовательская работа, посвященная изучению истории становления военного завода «Коммунар». Так сложилось, что история школы № 11 тесно связана с летопи- сью этого героического завода, взявшего шефство над школой.

С 2020 года в школе реализуется проект «Память поколений». В рамках реализации этого проекта Советом Народного краеведческого музея-комплекса имени заслуженного учителя Российской Федерации Павла Моисеевича Петренко проведена большая поисковоисследовательская работа по восстановлению памяти о военном заводе «Коммунар»: изучены архивные документы, проведены встречи с ветеранами завода, анкетирование и интервьюирование жителей района, сбор предметов, касающихся истории завода, собраны воспоминания заводчан, фотоматериалы из личных архивов жителей Кировского района. С каждым новым воспоминанием мы погружаемся в прошлое нашей страны, города Кемерово, Кировского района. В семьях хранятся старые фотографии, письма, награды, личные вещи тех, кого с благодарностью вспоминаем мы сегодня. Ветераны завода, жители района поделились 
своими реликвиями с нашим школьным музеем. Собранного материала стало достаточно для открытия в музее экспозиции «Память поколений. Нашим шефам - заводу «Коммунар» посвящается».

Представленные материалы иллюстрируют историю завода, его почти семидесятилетнюю деятельность.

\section{1. Строительство Кемеровского завода «Коммунар}

Строительство Кемеровского завода «Коммунар» было развернуто в 1940 году и организовано на общей площади с Кемеровским химическим комбинатом. Однако с целью более быстрого создания мощностей по производству взрывчатых веществ объект выделили в самостоятельный Союзный государственный завод по производству взрывчатых веществ № 319 (далее - ВВ № 319). Планировалось строительство цехов по производству гексогена, тротила, пикриновой кислоты и других веществ. Кроме того, цехов по денитрации и регенерации отработанных кислот [1, с. 124-130].

Планы мирного строительства прервала война. Кировский район стал жить по законам военного времени. Именно в годы Великой Отечественной войны происходило становление большинства химических и оборонных предприятий района. Был откорректирован проект строительства завода № 319 и пересмотрены сроки ввода цехов в эксплуатацию. При этом эвакуация ряда специализированных заводов из центральной части СССР на Урал и Восток потребовала размещать заказы на часть оборудования на предприятиях местной промышленности, что также повлияло на сроки ввода мощностей.

По решению Государственного комитета обороны перед руководством завода № 319 была поставлена задача приемки эвакуированного оборудования заводов и персонала из города Горловка и Рубежанского завода «Заря». Необходимо было подготовить жильё для прибывших, выполнить монтаж оборудования в недостроенных зданиях цехов, приспособить непроизводственные помещения под выпуск взрывчатых веществ. В сентябре 1941 года по Постановлению Государственного комитета обороны в Кировский район прибыли первые эшелоны с оборудованием из Сталинской (ныне Донецкой) области. В декабре приемка 245 единиц оборудования и 28 специали- стов была закончена. По приказу Народного комиссариата боеприпасов СССР (далее - НКБ СССР, Наркомат боеприпасов СССР) в Кемерово также была эвакуирована и пожарная часть НИИ-6 НКБ-56 [2].

Начальник первого эвакуационного эшелона Ф. В. Валеев, принявший руководство заводом, начал работы по монтажу оборудования в октябре. С октября по декабрь прибывающие эшелоны разгружались на площадке завода № 319 круглосуточно. В двух недостроенных цехах по производству взрывчатых веществ уже устанавливались станки, аппараты, механизмы. Спешно сооружались заводские корпуса, жилье. Преодолевая неимоверные трудности военного времени: жестокие сибирские морозы, недостаток питания, теплой одежды и обуви, жилищные неудобства, инженерно-технические работники и рабочие неделями не уходили с завода. Люди трудились сутками на холоде, при свете ламп, проявляя большую изобретательность и силу духа. В числе умельцев-изобретателей того времени на заводе называли И. П. Миленина, В. С Фолина, И. Д Панина. В цехах, готовящихся к пуску, увеличивались штаты инженернотехнических специалистов. Особое внимание уделялось цеху № 8, который планировалось запустить первым. 2 января 1942 года были назначены главные специалисты и руководство этим цехом (рис. 1). В течение всего строительства и пуска цехов заводом руководили Ф. В. Валеев, директор с 1940 года по 1942 год, и главный инженер Х. М. Адаскин [3].

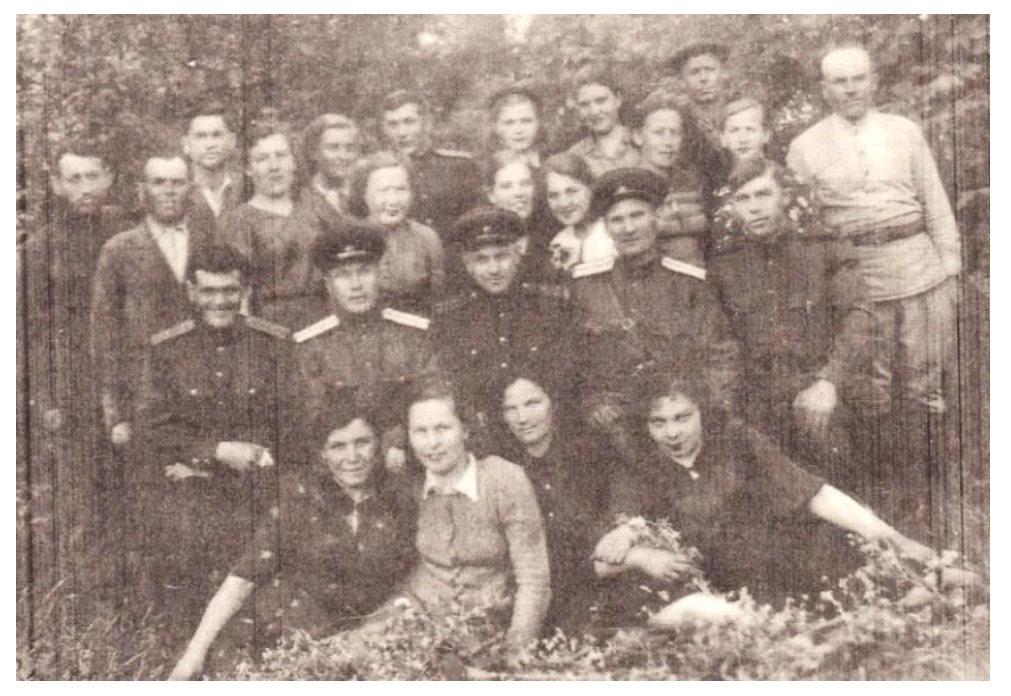

Рис. 1. Инженерно-технические работники цеха № 4 завода №319, 1944 год

С апреля 1942 по июнь 1963 года завод возглавлял инженер-подполковник Михаил Кузьмич Романов, до этого работавший директором Горловского химзавода № 64. Свой тру- 
довой путь М. К. Романов начал в 12 лет, учился без отрыва от производства. Член КПСС с 1931 года, в 1936 году окончил Артиллерийскую академию имени Ф. Э. Дзержинского в Ленинграде и в мае 1939 года был назначен директором Горловского химического завода. М. К. Романов, благодаря энергии, самоотверженности, таланту организатора, обеспечил эвакуацию людей и оборудования в Кемерово, вместе с коллективом обеспечил своевременный пуск столь необходимой для фронта продукции. Он был награжден двумя орденами Ленина, орденом Красной Звезды и четырьмя медалями: за победу над Германией, за победу над Японией, за доблестный труд в Великой Отечественной войне, за освоение целинных земель (рис. 2).

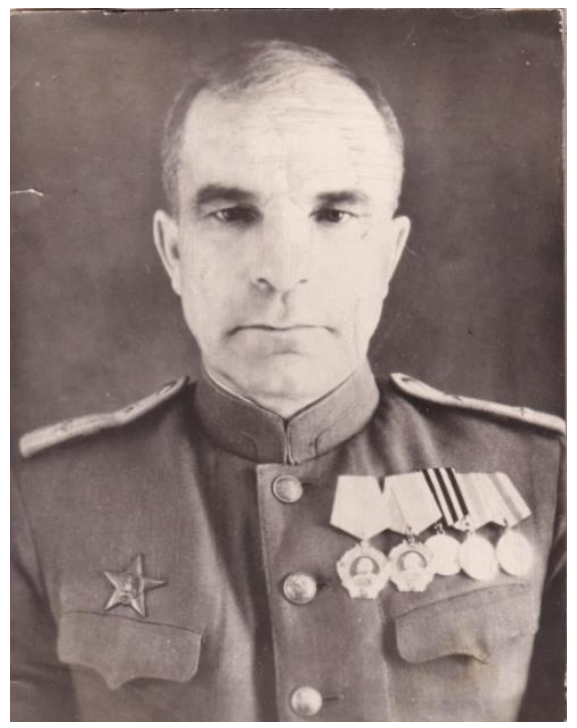

Рис. 2. Романов Михаил Кузьмич,

директор завода «Коммунар» с 24.04.1942 г. по 24.04.1962 г. Кавалер ордена Ленина

Строительство завода было закончено в 1942 году. Производственная площадь составила 9970 кв. м. Численность персонала на декабрь 1942 года составляла 1847 человек. Мощное взрывчатое вещество гексоген стал первым продуктом, поставленным для нужд фронта. В кратчайшие сроки, в течение 1,5 месяцев, технологический процесс был адаптирован к приспособленным непроизводственным помещениям.

\section{2. Завод № 319}

в годы войны 1941-1945 г2.

20 января 1942 года выпущена первая партия гексогена. Акт о выпуске и качестве первой оборонной продукции подписал начальник ОТК и военной приемки завода № 319 Василий Миронович Плешаков. Этот день стал началом истории завода. В связи с пуском производства наркоматом боеприпасов СССР был издан приказ № 40, в котором «за успешное окончание монтажа, пуск и освоение производства на заводе № 319» объявлялась благодарность руководителям, инженерно-техническим работникам, трудящимся.

В этом же год был освоен процесс флегматизации гексогена, разработанный коллективом ученых НИИ-6, эвакуированного в город Кемерово [4, с. 28-31].

Несмотря на перебои с поставкой сырья, успешно осваивались новые и увеличивались проектные мощности. 19 мая 1942 года вышло постановление о производстве на заводе пикриновой кислоты. Работа не прекращалась ни днем, ни ночью. Люди жили в бараках, где не хватало самого необходимого: тепла, коек, табуреток, кипяченой воды. Основными работниками были женщины, старики и подростки. Но при этом стахановцами и ударниками производства были $32 \%$ рабочих. Пример в работе подавали такие труженики, как В. Д. Федькин, П. Н. Овчинников, А. К. Фомина, А. М. Пискачева. В тяжелейших условиях люди не только выполняли, но и перевыполняли производственные задания. А выполнить норму было непросто, причем срыв графиков сдачи готовой продукции в условиях военного времени рассматривался как саботаж. Жесткость контроля держала в напряжении и руководство, и весь заводской коллектив. В августе 1942 года начальник, технолог, механик, энергетик цеха и руководство мастерских были переведены на казарменное положение. Им разрешалось отлучаться с территории завода только по производственным вопросам и в столовую. Ежедневно отправлялись отчеты в Наркомат боеприпасов.

Завод быстро рос, наращивал производство взрывчатых веществ, хотя и не такими ускоренными темпами, как хотелось. Несмотря на перебои с поставкой сырья, успешно осваивались новые и даже увеличивались проектные мощности. Все же не хватало специалистов, квалифицированных рабочих. Обучение персонала было организовано прямо в цехах. Завод стал одним из крупнейших в стране поставщиков гексогена, который применялся для производства капсюлей-детонаторов и снаряжения боеприпасов. Все это позволило увеличить выпуск бронебойных снарядов.

Не миновала завод и тяжелая катастрофа: 23 октября 1942 года произошел мощный взрыв, уничтоживший цех № 8. При взрыве погибли 22 человека, в том числе и начальник цеха С. А. Головачев. 
Преодолев тяжелые последствия взрыва, коллектив продолжал работать, производственные программы выполнялись. Вторая очередь производства гексогена после ликвидации последствий взрыва возобновила работу уже в ноябре 1942 года. За самоотверженный труд и организацию производства гексогена в невиданно сжатые сроки многие заводчане были удостоены правительственных наград. В числе награжденных Орденом Красной Звезды бывший начальник цеха С.А. Головачев (посмертно), технолог цеха П.Ф. Ульянов (посмертно). Были отмечены наградами такие труженики производства, как С. Н. Ушакова, А. В. Дуева, Е. Е. Поторокина и другие [5].

В апреле 1943 г. завод начал выпуск тротила. Руководил цехом С. С. Воронин. Оборудование для производства тротила было эвакуировано с Горловского химического завода и поступало частями в условиях военного времени. Инженернотехнологическая служба во главе с главным технологом завода Г.И. Мельниковым, внедряла важные технологические разработки, которые способствовали выполнению заданий для фронта и развитию оборонной промышленности. В марте 1943 года главный технолог завода Г. И. Мельников был удостоен Сталинской премии.

В 1943 году стабильно росли производственные показатели, заводчане увеличивали выпуск боеприпасов, сводки с фронта уже не были столь горькими, как в 1941 году. Но работа по выпуску взрывчатых веществ всегда сопряжена с опасностью. 19 мая 1943 года вновь случилась трагедия - произошел взрыв, который разрушил цех № 2, производивший тротил. Погибли 12 человек, в том числе и начальник цеха С. С. Воронин.

Огромное мужество и героизм при ликвидации последствий взрыва проявили пожарные ВПК-5. Начальник части Я. А. Тюнькин вместе со своим заместителем В. М. Васильевым и помощником В. В. Федоровым, командирами отделений Е. Г. Ревайкиным, А. И. Глушневым, А. И. Казакевичем, Д. С. Новиковым, политруком Д. Л. Матвеевым и личным составом дежурного караула боролись с огнем, чтобы спасти людей, уберечь склад готовой продукции и отделение сушки. 22 пожарных погибли, остались в живых только двое человек из дежурного караула: Иван Тимофеевич Величко и Филипп Трофимович Глущенко. Только в 1996 году вышел указ президента Российской Федерации о награждении медалью «За отвагу» сотрудников первого отделения пожарной охраны города Кемерово.
На восстановление цеха потребовалось пять месяцев, и в октябре 1943 года вновь начался выпуск тротила, а к июню 1944 года была достигнута проектная мощность. За восстановление цеха приказом Наркомата боеприпасов Льву Евгеньевичу Баскакову была вынесена благодарность с вручением именных часов. В 1945 году он был награжден Орденом Красной Звезды и назначен начальником цеха. В памяти заводчан также остался подвижнический труд мастеров цеха: Т. Т. Зозули, Г. И. Ковтун, С. Н. Ушаковой, А. К. Бордоговой.

Большую часть рабочих составляла молодёжь. Основная тяжесть заводского труда в военное время легла на плечи девушек и женщин, которые составляли $70 \%$ от всего персонала. Девушки приходили со школьной скамьи, учились на производстве, затем становились аппаратчицами, бригадирами. В 1944 году было создано 39 комсомольско-молодежных бригад. Среди них было развернуто соревнование под девизом «Все для разгрома врага!».

Больших успехов в труде добились молодежные бригады Грызуновой Антонины Ивановны, Кузмичевой Тамары Александровны, Максименко Евдокии Матвеевны, Дикушковой Нины Николаевны. Комсомолец М. П. Черенков успешно руководил бригадой слесарей. За самоотверженный труд в годы войны орденами и медалями были награждены 1438 человек.

Заводчане не только трудились в цехах, они помогали подшефным предприятиям - шахте «Северная», МГС «Тяжинский». Завод оказывал помощь школам района, помогал строить жильё, детские сады, собирать посылки для фронта. Заводчане собирали деньги для выпуска самолета и танка, держали свое подсобное хозяйство. В 1943 году было заложено в хранилище 900 тонн картофеля и других овощей.

Большое внимание администрация предприятия уделяла подготовке кадров. Было подготовлено 957 аппаратчиков, слесарей, токарей. На курсах повышения квалификации обучалось 2730 человек, в стахановских школах - 576 человек [6, с. 155-156].

\section{3. Главное богатство завода - его люди}

За самоотверженный труд в годы Великой Отечественной войны орденами и медалями награждены 1438 работников завода. Орденом Красной звезды награждены С. А. Головачев (посмертно), Л.Е. Баскаков, И.А. Остапенко; орденом Трудового Красного знамени Л. Е. Баскаков. Главный технолог производства 
Г. И. Мельников был удостоен Сталинской премии.

За самоотверженный труд в послевоенные годы 270 работников завода «Коммунар» были награждены орденами и медалями. Антонина Александровна Рыбакова награждена Орденом Ленина. Орденом Трудового Красного Знамени - А. И. Перекраснов, А. К. Бардогова, Р. Ф. Толкачев, Р. Ф. Салихов, П. П. Науменко, К. А. Смирнов, С. А. Градусов. Орденом Трудовой славы III степени - Лысенко, М. П. Лаврин, Н. И. Фадеева. Орденом «Знак Почета» М. И. Селиванова, Н. М. Петровский, С. А. Градусов, М. П. Лаврин, Н. И. Фадеева.

В трудовую летопись завода навсегда вошли имена женщин, долгое время особенно самоотверженно трудившихся в цехах завода «Коммунар».

Евдокия Елизаровна Поторокина работала на заводе «Коммунар» с 1942 года по 1994 год, общий стаж работы - 52 года. Евдокия Елизаровна награждена медалями: «За доблестный и самоотверженный труд в годы ВОВ», «За трудовую доблесть», «За трудовое отличие», «Знак «Отличник качества», «Ветеран труда», «40 лет Победы в ВОВ», «50 лет Победы в ВОВ».

Кузнецова Татьяна Семёновна трудилась на заводе с 1943 года по 1972 год, в цехе грануляции. За добросовестный труд награждена медалями: «За доблестный труд в ВОВ», «40 лет победы в $\mathrm{BOB} »$, «50 лет Победы в ВОВ», «Ветеран труда».

Степина Прасковья Ионовна работала в годы войны с 1943 по 1947, в мирное время - с 1970 по 1997. Прасковья Ионовна награждена медалями: «За доблестный труд в годы ВОВ», «50 лет Победы», «Ветеран труда».

Ерёменко Мария Иосифовна самоотверженно трудилась во 2-м цехе с 1942 года по 1972 год. Общий стаж работы - 35 лет. Награждена медалями: «За доблестный труд в годы $\mathrm{BOB}$ », «За доблестный труд» - к 100-летию со дня рождения В. И. Ленина, «За трудовое отличие», «За трудовую доблесть», «50 лет Победы в ВОВ», «Ветеран труда» [7].

Необходимо отметить руководителей комсомольско-молодёжных бригад:

Петровская Нина Ивановна приехала в Кемерово в 1941 году и работала на заводе по 1968 год. Награждена медалью «За Победу над Германией» и другими юбилейными наградами.

Максименко Евдокия Матвеевна также была руководителем комсомольско-молодёжной бригады. Работала на заводе с 1942 года по 1975 год, а с 1976 года по 1990 год трудилась в отде- ле технического контроля. Евдокия Матвеевна долгое время возглавляла ветеранскую организацию завода «Коммунар». Награждена медалями: «За доблестный труд», «За трудовое отличие», «За доблестный труд» - к 100-летию В. И. Ленина.

Радионова Анна Захаровна работала на предприятии с 1942 года по 1993 год. Награждена медалями: «За доблестный труд в $\mathrm{BOB}$ », «За трудовое отличие», «За доблестный труд», «Ветеран труда» и другими наградами.

Тришкина Зинаида Григорьевна трудилась на заводе «Коммунар» с 1942 года по 1965 год. Она являлась активистом ветеранской организации. Награждена медалями: «За трудовое отличие», «За трудовую доблесть» и другими наградами.

Ватолина Валентина Елисеевна работала с 1942 года по 1969 год оптиком-мастером. Награждена медалями: «За доблестный труд в ВОВ», «За трудовое отличие», «За трудовую доблесть» и другими юбилейными наградами.

Слесарь-инструментальщик

РТИ

В. И. Чеклецов стал лауреатом премии Ленинского комсомола.

Крупнотоннажное многостадийное производство тротила являлось настоящей школой мастерства для технологов, механиков и организаторов производства.

\section{4. Трудовые династии}

Среди тех, кто внес неоценимый вклад в строительство, освоение и развитие предприятия, нельзя не отметить заводские династии.

Основатели этих династий начали трудовую деятельность в первые годы войны. На смену им приходила молодёжь. Работали семьями на заводе, который становился родным для этих людей.

Глава династии Дуевых Анатолий Васильевич (1922 года рождения) после окончания Дзержинского химического техникума работал на Горловском химическом заводе. Вместе с этим заводом прибыл в Кемерово на завод «Коммунар», тогда еще ВB №319. Анатолий Васильевич работал аппаратчиком, мастеромтехнологом, старшим мастером, начальником смены, начальником участка, инспектором по технике безопасности. Является ветераном войны и труда, проработал на заводе 36 лет. А. В. Дуев награжден медалями: «За доблестный труд», «За Победу над Германией», «За трудовое отличие», «За трудовую доблесть».

На заводе работала мастером-технологом и его жена. Она также ветеран войны и труда, 
награждена медалью «За доблестный труд в ВOВ». Семья воспитала четырех детей, трое из которых являлись работниками предприятия. Сын Дуевых Владимир Анатольевич был механиком цеха БХ, профсоюзным лидером завода, позже - заместителем главного механика. Дочь Ольга Анатольевна работала инженером в цехе Кип и А инженером, затем - начальником цеха. Другой сын работал водителем, его жена также работала на заводе. Внук Анатолия Васильевича Сергей, закончив учёбу, тоже пришёл на завод. Общий стаж трудовой династии составил 138 лет [8].

Глава династии Кривобрюховых - Андрей Семенович (1916-2002 гг.). Андрей Семенович - инвалид Великой Отечественной войны, награжден орденами: «Орден Отечественной войны», «Орден Красной Звезды», медалью «За Победу над Германией», медалью «За доблестный труд в ВОВ». Добровольцем ушел на фронт в составе 22 Сибирской гвардейской дивизии, воевал на центральном фронте под городом Ржевом Калининской области. Андрей Семенович был тяжело ранен. После возвращения домой с 1941 года работал на заводе «Коммунар». На предприятии трудились и два его сына, жены сыновей. Общий стаж династии Кривобрюховых - 134 года.

Иван Ильич Еременко приехал из города Горловка в 1941 году, когда производство на заводе ВВ № 319 только начиналось. Почти всю жизнь он посвятил производству тротила. Работал мастером, начальником участка. После выхода на пенсию трудился в этом же цехе слесарем. Четверо его детей - три сына и дочь также трудились на заводе «Коммунар». Общий стаж династии Еременко составил 141 год.

$$
* * *
$$

На наш взгляд, оптимальный способ систематизировать результаты проведенной коллективом музея, увековечить память о самоотверженных тружениках завода «Коммунар», донести историю завода до читателя и, в первую очередь, до подрастающего поколения (ибо уважение к истории своей родины, гражданская позиция и патриотический дух должны воспитываться в человеке с детских лет) - это издание книги. Поэтому вполне закономерным итогом работы над проектом стала публикация книги «Память поколений», ставшей ценным историческим источником минувшей эпохи: военного времени, социалистического строительства, тяжёлых лет перестройки и 2000-ых годов. В этом издании собраны уникальные документы и фо- тографии, наглядно демонстрирующие рабочие процессы, быт, и главное, - жизнь людей, создающих будущее кемеровского завода «Коммунар». Верить и видеть, стремиться и достигать результата, в тяжелые, для страны в целом и для каждого человека в частности, времена одно из самых ценных качеств того, казалось бы, далекого и уже романтизированного поколения. Однако, со страниц книги, на читателя смотрят обычные люди, взрослые и дети, ничем не отличающиеся от читателя. Книга «Память поколений» имеет несомненную значимость и направлена на гражданско-патриотическое воспитание школьников для формирования и развития социально-активной личности гражданина и патриота, обладающей чувством национальной гордости, гражданского достоинства, любви к Отечеству, своему народу и готовностью к защите. Поисковый материал уникален, так как завод был «закрытым военным» предприятием и сведения о нем длительное время были минимальны.

Всего издано 100 экземпляров книги, часть из них подарена ветеранам завода, оставшиеся экземпляры распределены между школьными библиотеками и музеями города Кемерово. Коллектив музея выражает надежду, что это исследование будет способствовать сохранению памяти о героях-кемеровчанах. Это тем более необходимо, что в настоящее время возрождается интерес у подрастающего поколения к истории родного края. Поэтому поисковоисследовательское направление музейной работы в краеведении становится важным элементом современной жизни.

Таким образом, страницы издания «Память поколений» наглядно демонстрируют читателю, что трагическая история страны тесно переплетается с историей становления «Кемеровского завода «Коммунар», в которой как в зеркале войны отразилась гибель людей и героизм при ликвидации последствий взрывов, ежедневный трудовой подвиг, приближающий победы на фронтах Великой Отечественный войны, все это Страна, победившая в самой страшной войне прошлого века, восстанавливается, что так же находит отражение в представленных фотографиях: людей, в военной форме, постепенно заменяют люди в рабочих халатах, ручные станки заменяются автоматизированными агрегатами, появляются первые рабочие династии. Особую ценность представляют воспоминания очевидцев, описанных в издании, событий. И особенно важно, объективно транслировать исторические события страны через становление и развитие 
«Кемеровского завода «Коммунар», для современного подрастающего поколения, показать ту цену, которую заплатили практически все семьи трудового региона.

\section{Список литературы}

1. Специалисты по взрывчатым материалам, пиротехнике и боеприпасам: биогр. энцикл. Москва, 2006. $701 \mathrm{c}$.

2. ГАКО. Ф.200. Оп.1. Д.55. Л. 11-12; Д.69. Л.25, 27, 38; Д.94. Л.32-33; Д.121. Л.13, 33, 40, 72.

3. ГАКО. Ф.204. Оп.3. Д.1. Л.37, 284, 345, 415; Д.2. Л.61, 111, 323; Ф.304. Оп.4. Д.3990. Л.1-2; Д.3995. Л.11-13.
4. Болтовский О. В. Создание и деятельность завода № 319 в военные годы // Город Кемерово в годы Великой Отечественной войны. Кемерово, 2000. 156 с.

5. ГАКО. Ф.75-П. Оп. 1. Д.33. Л.1, 9, 10, 21-23,41-42, 46-47; Ф.304. Оп. 4. Д.3971. Л.77; Д.4684. Л.10, 16, 21.

6. Шуранов Н. П. Кузбасс в годы Великой Отечественной войны. Кемерово, 2000. 179 с.

7. Кировский район. Вехи истории: 19342009. Кемерово, 2009. 159 с.

8. ГАКО. Ф.75-П. Оп. 1. Д4. Л.4-5, 13,16 , 18; Ф.304. Оп.4. Д.54. Л.18; Д.3972. Л.11-12, 26; Ф.461. Оп.2. Д.2. Л.10, 191; Ф.797. Оп.1. Д.133. Л.42-43.

УДК 130.2:342.813+159.924.24

DOI: $10.32340 / 2514-772 X-2021-1-40-43$

И. Н. Каланчина, кандидат философских наук, доцент Алтайский государственный аграрный университет (Барнаул, Россия) kalanchina62@mail.ru

\section{АКСИОЛОГИЧЕСКАЯ ЛИНГВОМЕТОДИКА КАК СРЕДСТВО АКТУАЛИЗАЦИИ ЛИЧНОСТНОГО НАЧАЛА В ПЕДАГОГИЧЕСКОЙ ПРАКТИКЕ}

Аннотация. Проблема реализации интеллектуальных, творческих способностей современной молодежи имеет множество аспектов. Среди них важное место занимает наличие идейного компонента в содержании воспитательных и образовательных программ. По мнению автора, применение принципов природосообразности, идеалосообразности и аксиологической лингвометодики позволяет «пробудить» индивидуальность студента, так как ценностный подход является очень важным для формирования зрелой личности.

Ключевые слова: философия образования, иенностно-ориентированный подход в образовании, философия культуры, аксиологическая лингвометодика.

Образование в его подлинном значении является важнейшим фактором развития как отдельного человека, так и всего общества. Поэтому важным критерием, определяющим, насколько успешно система образования выполняет данную функцию, является показатель реализации личностного начала и учащегося, и преподавателя. И совершенно очевидно, что современную ситуацию с этой точки зрения трудно назвать благополучной.

Проблема реализации интеллектуальных, творческих способностей современной молодежи (самого широкого диапазона: от детей дошкольного возраста до выпускников колледжей и вузов) имеет множество аспектов. Среди них можно отметить, такие как уровень и качество государственного управления и законодательно- правовая база в сфере воспитания и образования, социальный статус педагога (воспитателяучителя-преподавателя), уровень соответствия идейной составляющей (ее глубокая проработка или же формальная имитация работы в этом направлении) национальным интересам сохранения суверенитета и всестороннего развития государства и др.

В данной статье мы остановимся на одном из важных аспектов - идейном содержании воспитательно-образовательного процесса, а конкретно - насколько оптимально используются в воспитательно-образовательном процессе возможности предметов гуманитарного цикла и, особенно русского языка и производных от него дисциплин (в частности, русский язык и культура речи, деловое общение, речевая культура 